\title{
On the Cover
}

Portions of the following are based on an interview with the artist on June 23, 2005.

Spirals, suggests Toronto artist Mosa Neshamá McNeilly, speak of potentiality. Like the birth or rebirth of light and life, present in so many of the world's traditions at this time of year, spirals are a hopeful concept. McNeilly contrasts spirals with circles, which "go around and around on the same plane as though not learning from experience, not growing or transforming. Spirals represent the cosmic life force and the intrinsic promise of existence- the possibility of evolving consciousness."

With Grenadian, Jewish, Scottish, Romanian, Caribbean, and African roots, McNeilly grew up in Toronto, then somewhat less of a multicultural mecca than it currently is. She says that she struggled with questions of identity and belonging and spent years "making and remaking sense of my diverse heritage, longing to feel like a whole person." Her name serves to embody that diversity: Mosa (Sesotho for "compassion"), Neshamá ("soul" in Hebrew), McNeilly (reflecting the history of the Scots in Grenada).

Early engaged in multiple artistic interests, McNeilly studied at the Royal Conservatory of Music in Toronto, the Parsons School of Design in New York, and the Toronto Dance Theater, ultimately obtaining her art diploma from the Ontario College of Art and Design. Her art "draw[s] from a myriad of traditions, including Western arte povera, Aboriginal and African ceremonial sculpture, and AfricanAmerican folk art ... form[ing] a unique style which suggests strong links to a larger global community" (Edmonds, 2004, p. 1).

By the early 1990s, McNeilly had become particularly intrigued with making use of "found objects" in mixed media on canvas and installations. On a trip to Colombia in 1993, during which she lived on a beach in Arecife, McNeilly collected the stones that form the outer layer of Spiral, shown on the cover of this issue:

I am in awe of nature. To be ensconced in nature, that is when I feel most human. The Aboriginal people of Canada speak of walking gently on the earth. We can allow ourselves to be affected by the delicate beauty and the fierce power of nature and feel then compelled to be good stewards of this planet. ... I am always seeking to behold beauty, perhaps to counter the ugliness of the damage we do as humans to each other and to the earth. In my work, stones are representatives of the earth. A stone holds great mystery for me. Its surface is so smooth, its form so gently curved-and yet it is so dense and solid and hard. It fits in the palm of my hand today; at the same time, it is ancient, and the grains of sand that are its mass may come from many mountains the world over.

McNeilly comments that the gathering and assembling of objects such as these is a symbolic act, "which parallels, in part, the inner process of the ordering of my cultural diversity":

Each stone is so individual in its color, shape, and size-yet with all their nuances of individuality, when placed together they are clearly all stones. I think it is the promise of containment of the paradox of difference and sameness here that I find so compelling.
The central spiral, vibrant and shimmering, is constructed of paper, plaster, gauze, metallic pigment, and acrylic. It streams out from a fetuslike, energizing core, gathering momentum as it unfolds. McNeilly says that it speaks to yet further layers of meaning in relation to feminine sexuality.

McNeilly works as a "multidisciplinary artist and arts educator in the visual and the performing arts ... embracing and conveying the complexity of [her] cultural diversity and artistic multiplicity":

As a visual artist, I have explored themes of identity, gender and spirituality, often with an environmentalist subtext. In creating multilayered representations of these themes, through the interrelation of image, object, and symbol, I have hoped to convey the complex tasks of seeking to belong, of observing the shifting sense of self, and of making sacred one's own experience.

This assemblage, presented flat on the floor, was first installed in 1994 and has had several "incarnations" since:

Each time, the installation process is an exercise in trusting the synergy of my intuition. It is like improvisation in movement or voice, allowing for the randomness of placement within the loose structure of rhythm and pattern, giving the work a little room to breathe on its own.

In her work in the visual arts, dance, and music, McNeilly has come to see that each discipline serves to inform the other. Languages overlap: One may speak of texture, tone, or composition in music or the visual arts. The journalist Lawrence Weschler (2004), grandson of Austrian American composer Ernst Toch, similarly wrote of this intermixture:

Whenever I write, or review my own or other people's writing, almost all my judgments about the process tend to get framed in musical metaphors: questions of pacing, modulation, tone, harmonics, counterpoint.... I have a profound sense that I am engaged in a compositional enterprise involving the sequential deployment of material across time in a "formful" manner, which is to say within a transparent architectonic (one of my grandfather's favorite words) structure. (p. 214)

With all the complexity that informs McNeilly's artistic expression, it is perhaps no surprise, finally, that she describes herself as having a passion for psychology, especially psychology from a "soul-ful" slant. Musing through the inner world of her art, she says, is not unlike the textures of psychological reflection, with its multiple meanings, layers, and undercurrents.

\section{REFERENCES}

Edmonds, P. (2004). Soulful communion: Artist's poetic handiwork explores elemental powers of nature, community and spirit. Retrieved August 15, 2005, from www.studiovisuals.com/images/ Soulful\%20Communion.pdf

Weschler, L. (2004). Vermeer in Bosnia. New York: Pantheon.

Kate F. Hays Guest Art Editor 